INTERNATIONAL JOURNAL OF PLANT PROTECTION VOLUME 9 | ISSUE 2 | OCTOBER, 2016 | 632-634
- e ISSN-0976-6855 | Visit us : www.researchjournal.co.in

\title{
In vivo efficacy of garlic extract and yeast for the control of post harvest diseases of mango and papaya
}

\author{
R.P. SHINDE*, B.G. BARHATE AND N.A. MUSMADE
}

Department of Plant Pathology, Mahatma Phule Krishi Vidyapeeth, Rahuri, AHMEDNAGAR (M.S.) INDIA

\section{ARITCLE INFO}

Received : 29.02.2016

Accepted : 20.09.2016

\section{KEY WORDS :}

Mango, Papaya, Post harvest, Garlic extract, Yeast

\begin{abstract}
The present investigations were carried out with collection of diseased samples, isolation of the organisms responsible for post harvest spoilage, their pathogenicity, symptomatology and morphological characters in order to suggest suitable control measures in respect of yeast as a bioagent and garlic extract as a botanical in controlling post harvest fungal diseases of mango and papaya. The causal organisms was isolated from infected fruits and recorded association of four fungal pathogens viz., Aspergillus niger, Colletotrichum gloeosporioides, Alternaria alternata, and Rhizopus stolonifer. The pathogenicity of all pathogens was proved by artificial inoculation method. The conidial size of A. niger, A. alternata, , C. gloeosporioides, and $R$. stolonifer measured as $4.4 \mu \mathrm{m}, 42.47 \times 16.37 \mu \mathrm{m}, 9.50-18.56 \times 2.68-6.72 \mu \mathrm{m}$ and $125 \times 294.1 \mu \mathrm{m}$ in size (average), respectively. Use of 5 per cent yeast, (Eremothecium cymbalariae) was found effective against Aspregillus niger and Colletotrichum gloeosporioides .1 per cent garlic extract was found effective against Colletotrichum gloeosporioides and Alternaria alternata, but not much effective against Alternaria alternata on papaya fruits. Both yeast and garlic extract increases shelf-life and market quality of fruits, with increase in glossiness of fruits.
\end{abstract}

How to view point the article : Shinde, R.P., Barhate, B.G. and Musmade, N.A. (2016). In vivo efficacy of garlic extract and yeast for the control of post harvest diseases of mango and papaya. Internat. J. Plant Protec., 9(2) : 632-634, DOI : 10.15740/HAS/IJPP/9.2/632-634. 